undifferentiated multicellularity. Proc Natl Acad Sci U S A 100, 1095-1098.

Pfeiffer, T., Schuster, S. \& Bonhoeffer, S. (2001). Cooperation and competition in the evolution of ATP-producing pathways. Science 292, 504-507.

Picioreanu, C., Kreft, J.-U. \& van Loosdrecht, M. C. M. (2004).

Particle-based multidimensional multispecies biofilm model. Appl Environ Microbiol 70, 3024-3040.

Rainey, P. B. \& Rainey, K. (2003). Evolution of cooperation and conflict in experimental bacterial populations. Nature 425, 72-74.

Sigmund, K. (1994). Games of Life. Oxford: Oxford University Press.

Travisano, M. \& Velicer, G. J. (2004).

Strategies of microbial cheater control.

Trends Microbiol 12, 72-78.

Turner, P. E. \& Chao, L. (2003). Escape from Prisoner's Dilemma in RNA phage $\phi 6$. Am Nat 161, 497-505.

Vasiev, B. \& Weijer, C. J. (1999). Modeling chemotactic cell sorting during Dictyostelium discoideum mound formation. Biophys J 76, 595-605.

Velicer, G. J. (2003). Social strife in the microbial world. Trends Microbiol 11, 330-337.

Velicer, G. J. \& Yu, Y. T. (2003). Evolution of novel cooperative swarming in the bacterium Myxococcus xanthus. Nature 425, 75-78.

Watnick, P. \& Kolter, R. (2000).

Biofilm, city of microbes. J Bacteriol 182, 2675-2679.

Webb, J. S., Givskov, M. \& Kjelleberg, S. (2003a). Bacterial biofilms: prokaryotic adventures in multicellularity. Curr Opin Microbiol 6, 578-585.

Webb, J. S., Thompson, L. S., James, S., Charlton, T., Tolker-Nielsen, T., Koch, B., Givskov, M. \& Kjelleberg, S. (2003b).

Cell death in Pseudomonas aeruginosa biofilm development. J Bacteriol 185, 4585-4592.

Westerhoff, H. V. \& van Dam, K. (1987). Thermodynamics and Control of Biological Free-energy Transduction. Amsterdam: Elsevier.

DOI 10.1099/mic.0.27415-0

\section{Fungus or bacterium and vice versa?}

Cavaletti \& Monciardini (2004) and Strobel et al. (2004) discussed whether an organism was fungal or bacterial. Indeed, mistakes continue to be made by calling streptomycetes fungi. Ergosterol is underestimated in its ability to distinguish fungi from others organisms. The lipid is practically unique to fungi, sufficient for its frequent use in quantification in environments with other organisms; it is not recorded in bacteria. Contamination of cultures may not be (such) a potential problem as with PCR, as targets are not of course amplified. We used the method to analyse fungi in water amongst other things (Kelly et al., 2003). In general, protocols involve refluxing for about $1 \mathrm{~h}$, phase separation and analysis by chromatography. TLC was used initially which could be adequate for the proposed purpose. However, HPLC is the method of choice and a hyphenated technique (e.g. HPLC-DAD/MS) would be beneficial. I found that a microwave extraction procedure was satisfactory and gave advantages of rapidity and small sample size (Young, 1995). Furthermore, fungi contain partially saturated and saturated ubiquinones whereas only the latter are detected in bacteria (Paterson, 1998). Of course, fungi do not possess menoquinones. Thus affiliation of the organism in question may be resolved if the analysis of ergosterol and perhaps the other compounds were undertaken.

\section{R. Russell M. Paterson}

Micoteca de Universidade do Minho, Centro de Engenharia Biologica, Campus de Gualtar, 4710-057 Braga, Portugal

Correspondence: R. Russell M. Paterson (email russell.paterson@deb.uminho.pt)

Cavaletti, L. \& Monciardini, P. (2004).

Congruence between strain morphology and the $16 \mathrm{~S}$ rRNA gene sequence. Microbiology 150, 3093-3094.

Kelley, J., Kinsey, G., Paterson, R., Brayford, D., Pitchers, R. \& Rossmore, H. (2003).

Identification and Control of Fungi in Distribution Systems. Denver, CO: Awwa Research Foundation and American Water Works Association.

Paterson, R. R. M. (1998). Chemotaxonomy of filamentous fungi by unsaponifiable lipids. In Handbook of Applied Mycology 6. Chemical Fungal Taxonomy, pp. 183-218. Edited by P. D. Bridge \& J. Frisvad. New York: Marcel Dekker.

Strobel, G. A., Exra, D. \& Castillo, U. (2004). A question concerning the identity of Streptomyces sp. MSU-2110. Microbiology 150, 3094-3096.

Young, J. C. (1995). Microwave-assisted extraction of the fungal metabolites ergosterol and total fatty acids. J Agric Food Chem 43, 2904-2910.

DOI 10.1099/mic.0.27732-0 